Original Research Paper

\title{
Nanoparticle Formula Optimization of Juwet Seeds Extract (Syzygium cumini) using Simplex Lattice Design Method
}

\author{
Yohanes Juliantoni ${ }^{*}$, Wahida Hajrin ${ }^{1}$, Windah Anugrah Subaidah ${ }^{1}$ \\ ${ }^{1}$ Program Studi Farmasi, Fakultas Kedokteran, Universitas Mataram, Mataram, Indonesia
}

\author{
Article History \\ Received : October $19^{\text {th }}, 2020$ \\ Revised : November $12^{\text {th }}, 2020$ \\ Accepted : November $15^{\text {th }}, 2020$ \\ Published : November $17^{\text {th }}, 2020$ \\ *Corresponding Author: \\ Yohanes Juliantoni, \\ Universitas Mataram, Mataram, \\ Indonesia; \\ Email: \\ juliantoni7753@gmail.com
}

\begin{abstract}
Diabetes is a degenerative disease whose numbers continue to increase from year to year. Treatment with oral antidiabetic drugs can cause harmful side effects for patients. One of the plants that can be used for diabetes therapy is juwet (Syzygium cumini L.). Flavonoid compounds of juwet seed is easily oxidized and hydrolyzed in intestinal fluids with low absorption. This problem can be overcome by forming nanoparticle of juwet seed extract. The aims of this study was to obtain the formula for juwet seed nanoparticles. Nanoparticle of juwet seed extract made by ionic gelation method with chitosan and Na-TPP polymers which are varied. The formula optimization design in this study was determined using a simplex lattice design by 3 variations of materials based on the parameters \%entrapment efficiency, \%transmittant, particle size, polydisperse index, and zeta potential. The results showed that the yield of duwet seed extract was 7,44\%. Juwet seed ethanolic extract contains $3.33 \mathrm{mg}$ of quercetin per $1 \mathrm{~g}$ of extract. Based on the desirability value approach, the optimum formula was produced with an extract composition of $1.650 \mathrm{~mL}$; chitosan $0.500 \mathrm{~mL}$; and Na-TPP $0.010 \mathrm{~mL}$ can give optimal results with a desirability value of 0.772 which results in the criteria of $63.66 \%$ entrapment efficiency; $50.56 \%$ transmittant; $615,833 \mathrm{~nm}$ particle size; $0.620 \mathrm{PDI}$; and zeta potential of $+13.89 \mathrm{mV}$. Juwet seeds extract can be formulated into the form of nanoparticles. To get better parameters, it is advisable to optimize the mixing time and mixing speed in the ionic gelation method.
\end{abstract}

Keywords: Syzygium cumini; Nanoparticle; Simplex Lattice Design

\section{Pendahuluan}

Diabetes mellitus merupakan suatu kelompok penyakit metabolik yang ditandai dengan terjadinya hiperglikemia, disebabkan oleh kelainan sekresi insulin, kelainan kerja insulin, atau keduanya. Prevalensi penyakit diabetes mellitus terus mengalami peningkatan dari tahun ke tahun. Hasil Riset Kesehatan Dasar tahun 2008 menunjukkan bahwa kejadian diabetes di Indonesia telah mencapai 57\%. Menurut Khairani (2007), prevalensi diabetes mellitus pada lansia adalah $15,8 \%$ dengan resiko yang lebih tinggi bagi wanita dibandingkan pria. Diabetes tipe 2 banyak disebabkan oleh gaya hidup yang tidak sehat. Terapi yang digunakan untuk pengobatan diabetes mellitus tipe 2 pada umumnya adalah dengan menggunakan obat antidiabetes peroral (Qaseem et al., 2012). Penggunaan obat antidiabetes sintetik ini memiliki efek samping adanya hipoglikemia yang membahayakan bagi pasien (Holstein \& Egberts, 2003).

Salah satu tanaman yang telah terbukti memiliki efek antidiabetes adalah biji juwet (Syzygium cumini L.). Penelitian yang dilakukan oleh (Kumar et al., 2008). menunjukkan bahwa ekstrak metanol dan ekstrak etil asetat biji juwet dapat menurunkan kadar glukosa darah tikus yang diinduksi streptozosin. Ekstrak etanolik biji juwet dapat menurunkan hemoglobin dan meningkatkan kadar insulin pada kelinci yang diinduksi oleh aloksan dan pada tikus yang diinduksi oleh streptozosin (Sharma et al., 2008). Efek antidiabetes biji juwet terkait dengan efek antioksidannya. Senyawa aktif dalam biji juwet adalah senyawa polifenol, antara lain golongan flavonoid, karotenoid, dan antosianin (Faria et al., 2011; Swami et al., 2012). Senyawa-senyawa polifenol diketahui memiliki stabilitas yang rendah karena mudah teroksidasi. Selain itu, senyawa flavonoid dalam tanaman biasanya 
berupa glikosida falavonoid, namun pada usus dapat terhidrolisis menjadi aglikonnya.

Efisiensi dari penggunaan obat selalu terhambat oleh kemampuan obat itu sendiri dalam mencapai tempat aksinya. Dalam banyak kasus (ukuran normal), hanya sedikit jumlah obat yang dapat mencapai target tempat aksi, sementara sebagian besar dari obat didistribusikan keseluruh tubuh sesuai dengan kandungan physicochemical dan biochemicalnya. Salah satu cara yang dapat dilakukan untuk mengatasi masalah tersebut adalah melalui pembentukan nanoenkapsulasi. Nanopartikel merupakan partikel koloid padat dengan diameter 1-1000 nm (Tiyaboonchai, 2013). Mengandung makromolekuler material dan dapat digunakan untuk pengobatan sebagai pembawa obat yang senyawa aktifnya telah terlarut, terjerat, dan encapsulated.

Kitosan merupakan polisakarida yang banyak terdapat di alam setelah selulosa. Kitosan merupakan suatu senyawa poli (N-amino-2-deoksi- $\beta$-Dglukopiranosa) atau glukosamin hasil deasetilasi kitin/poli (N-asetil-2-amino-2-deoksi- $\beta$-Dglukopiranosa). Kitosan mempunyai sifat spesifik yaitu adanya sifat bioaktif, biokompatibel, pengkelat, antibakteri dan dan dapat terbiodegrasi (Ramadhan et al., 2010). Namun demikian, kitosan hanya larut dalam media air dengan keberadaan sedikit asam dan sifat-sifatnya kurang baik untuk aplikasi biomedis (Zhang et al., 2002). Salah satu pemanfaatan kitosan dalam sistem biomedis atau biologis adalah pada sistem penghantaran obat dan pelepasan obat (Stamatialis et al., 2008). Pada sistem ini pelepasan obat dengan kitosan memiliki keterbatasan karena kitosan cepat sekali menyerap air dan memiliki derajat swelling yang tinggi dalam lingkungan berair, hal tersebut akan menyebabkan pelepasan obat terjadi lebih cepat (Alauhdin \& Widiarti, 2014).

Nanopartikel dengan polimer kitosan dapat melindungi senyawa aktif dari degradasi fisika maupun mikrobiologi (George \& Abraham, 2006; Lin et al., 2008). Selain itu, kitosan dapat menjadi enhancer untuk membantu meningkatkan permeabilitas atau absorpsi senyawa aktif (Schipper et al., 1997). Penelitian ini bertujuan untuk menentukan formula optimum nanopartikel ekstrak etanolik buah juwet menggunakan polimer kitosan dan cross-linker Na-TPP dengan metode gelasi ionik.

\section{Bahan dan Metode}

\footnotetext{
Alat dan Bahan

Bahan-bahan yang digunakan dalam penelitian ini adalah biji juwet, etanol $70 \%$, etanol 96\%, kitosan, natrium tripolifosfat, asam asetat glasial, aquadest. Alat yang digunakan dalam penelitian ini adalah magnetic stirrer, vial, particle size analyzer, spektrofotometer UVvis, mikropipet, blue tip, yellow tip, sentrifuge, spuit injeksi, alat gelas.
}

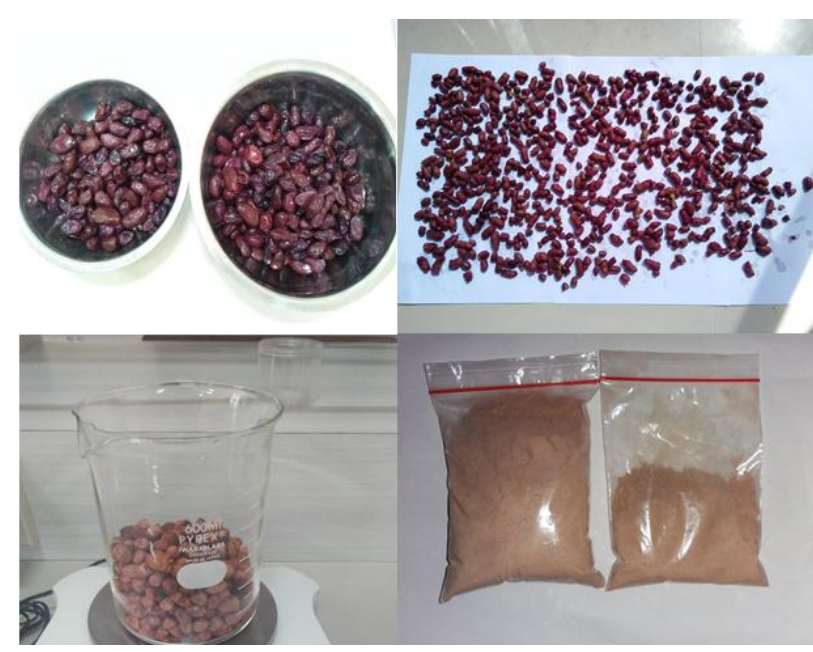

Gambar 1. Biji Juwet

\section{Pengumpulan Sampel}

Biji buah duwet diambil di desa Sembalun kabupaten Lombok Timur Provinsi Nusa Tenggara Barat.

\section{Ekstraksi}

Biji buah duwet diekstraksi dengan metode maserasi menggunakan pelarut etanol 70\%. Sebanyak $200 \mathrm{~g}$ biji duwet di ekstraksi dengan 1L pelarut aquadest. Ekstrak cair dikentalkan dengan menggunakan tangas air (suhu $<65^{\circ} \mathrm{C}$ ) sampai menjadi ekstrak kental.

\section{Karakterisasi Ekstrak}

Karakterisasi ekstrak etanolik biji buah duwet dimulai dari uji organoleptis, uji kualitatif flavonoid, dan uji kadar flavonoid total.

\section{Formulasi Nanopartikel}

Pembuatan nanopartikel diawali dengan pembuatan larutan ekstrak, kitosan, dan Na-TPP. Ekstrak etanolik biji juwet dilarutkan dalam etanol $96 \%$ dengan konsentrasi $0,5 \%$. Larutan induk kitosan dibuat dengan konsentrasi $0,5 \%$ dalam asam asetat $1 \%$, kemudian diaduk semalaman hingga kitosan melarut sempurna. Larutan induk Na-TPP dibuat konsentrasi $0,5 \%$ dalam aquadest.

Pembuatan nanopartikel ekstrak biji juwet dilakukan dengan mencampurkan larutan kitosan dan ekstrak diaduk selama 30 menit, kemudian Na-TPP ditambahkan tetes demi tetes hingga diperoleh perbandingan ketiga larutan adalah 1:1:1.

\section{Uji Formula Nanopartikel}

Formula nanopartikel ekstrak etanolik biji juwet dilakukan dengan dua cara yaitu uji entrapment efficiency dan uji \% transmittant. 


\section{a. Uji \% entrapment efficiency}

Campuran larutan pembuatan nanopartikel disentrifugasi kemudian dipisahkan antara endapan dan supernatannya. Supernatan diambil kemudian dilakukan pengukuran kadar flavonoid total ekstrak yang tidak terjerap. \% EE ditentukan dengan rumus berikut:

$$
\% E E=\frac{\text { TFC total }- \text { TFC supernatan }}{\text { TFC total }} \times 100 \%
$$

\section{b. uji \% transmittant}

Larutan campuran nanopartikel dimasukkan ke dalam kuvet kemudian dilihat \% transmittantnya menggunakan spektrofotometer UV-Vis pada Panjang gelombang $650 \mathrm{~nm}$.

\section{c. Karakterisasi Nanopartikel}

Ukuran nanopartikel diukur menggunakan Particle Size Analyzer (PSA). Ukuran partikel merupakan karakteristik yang paling penting dalam sistem nanopartikel karena mempengaruhi secara langsung keunikan sifat nanopartikel.

Zeta potential merupakan parameter muatan listrik antara partikel koloid. Semakin besar nilai zeta potensial maka akan semakin mencegah terjadinya flokulasi. Pengurangan nilai zeta potensial akan memungkinkan partikel untuk saling tarik-menarik dan terjadi flokulasi. Koloid dengan nilai zeta potensial yang tinggi (negatif atau positif) yang elektrik stabil sementara koloid dengan nilai zeta potensial rendah cenderung mengental atau terflokulasi. Idealnya, muatan potensial zeta partikel harus lebih tinggi daripada medium pendispersi untuk mencegah agregasi. Nanopartikel dengan nilai potensial zeta lebih kecil dari $-30 \mathrm{mV}$ dan lebih besar dari $+30 \mathrm{mV}$ memiliki stabilitas lebih tinggi (Murdock et al., 2008). Sistem dispersi dengan nilai zeta potensial yang rendah lebih mudah membentuk agregat seiring dengan gaya Van der Waals dalam interaksi partikel.

Indeks polidispersitas merupakan jumlah yang dihitung dari dua parameter sederhana untuk data korelasi. Nanopartikel dengan nilai PDI adalah 1 memiliki distribusi ukuran yang sangat luas dan mengandung partikel besar atau agregat yang dapat mengalami sedimentasi. Nilai PDI di bawah 0,05 biasanya dimiliki oleh sistem monodispersi.

\section{Optimasi Formula}

Optimasi Formula menggunakan metode Simpleks lattice design dengan Design Expert untuk mendapatkan formula optimal berdasarkan hasil uji \% entrapment efficiency, \% transmittant, Ukuran partikel, PDI, dan zeta potensial

\section{Hasil dan Pembahasan}

\section{Pengumpulan dan Preparasi Sampel}

Biji Duwet diambil di desa Sembalun kabupaten Lombok Timur Provinsi Nusa Tenggara Barat pada bulan september 2019. Biji duwet sebelum digunakan terlebih dahulu dibersihkan dari pengotor menggunakan air mengalir.

Ekstraksi dilaksanakan dengan cara maserasi yaitu Daging buah dan kulit dipisahkan dari bijinya kemudian biji dikeringkan, diblender dan direndam dengan etanol $70 \%$. Ekstrak dikentalkan dengan menggunakan waterbath. Ekstrak kental biji duwet disimpan dalam tempat kering tertutup sampai pada saatnya dipergunakan.

Pada penelitian ini dilakukan penetapan pada 2 parameter yaitu organoleptis dan rendemen ekstraksi. Pengujian organoleptis ekstrak (bentuk, warna dan bau) dilakukan dengan cara wadah tempat berisi sampel dibuka dan biarkan sampel terkena udara selama 15 menit kemudian data organoleptis dapat ditentukan. Namun harus diingat bahwa data organoleptis hanya merupakan data deskriptis dan bukan parameter penentu standar kemurnian ekstrak bersangkutan (Depkes RI, 2009).

Tabel 1.Data Organoleptis Ekstrak Biji Duwet

\begin{tabular}{ll}
\hline \multicolumn{1}{c}{ Organoleptis } & Keterangan \\
\hline Rasa & Pahit \\
Warna & Hitam \\
Bau & Khas \\
\hline
\end{tabular}

Ekstrak dapat dihitung rendemennya yaitu dengan mencari presentase bobot (b/b) ekstrak akhir dan serbuk simplisia kering untuk maserasi. Data rendemen ekstrak dapat dilihat pada perhitungan berikut :

$$
\begin{gathered}
\text { Rendemen }=\frac{\text { BeratEkstrakKental }}{\mathrm{BeratAwal}} \times 100 \% \\
\text { Rendemen }=\frac{34,06 \mathrm{gr}}{457,55 \mathrm{gr}} \times 100 \% \\
\text { Rendemen }=7,44 \%
\end{gathered}
$$

Ada beberapa hal yang diketahui dapat mempengaruhi mutu ekstrak, yaitu kebenaran tanaman, genetik, lingkungan tempat tumbuh, penambahan bahan pendukung pertumbuhan, waktu panen, penanganan pasca panen, teknologi ekstraksi, teknologi pengentalan dan pengeringan ekstrak serta cara menyimpan ekstrak.

\section{Skrining Flavonoid}

Ekstrak 0,1 gram dalam cawan ditambahkan $2 \mathrm{~mL}$ etanol kemudian diaduk, ditambahkan serbuk $\mathrm{Mg} 0,1 \mathrm{~g}$ dan 3 tetes $\mathrm{HCl}$ pekat. Larutan sampel setelah diuji berwarna kuning menunjukkan adanya hasil positif dari uji kualitatif flavonoid. 
Adanya flavonoid dalam sampel perlu ditegaskan kembali dengan uji kadar flavonoid total diawali dengan pembuatan kurva baku dengan menggunakan kuersetin sebagai pembanding. Hasil penentuan lambda maksimal bernilai $417 \mathrm{~nm}$ dengan operating time selama 20 menit.

Tabel 2. Uji Total Flavonoid Content

\begin{tabular}{cc}
\hline Kuersetin & Absorbansi \\
\hline $10 \mathrm{ppm}$ & 0,3078 \\
$15 \mathrm{ppm}$ & 0,4087 \\
$20 \mathrm{ppm}$ & 0,5062 \\
$25 \mathrm{ppm}$ & 0,6389 \\
$30 \mathrm{ppm}$ & 0,7556 \\
$35 \mathrm{ppm}$ & 0,854 \\
\hline
\end{tabular}

Didapatkan nilai $\mathrm{y}=0,0223 \mathrm{x}+0,0765$ dengan nilai $\mathrm{R}^{2}=0,9978$, absorbansi sampel dihitung dengan persamaan regresi linier untuk memperoleh kadar flavonoid total.

Tabel 3. Absorbansi Sampel

\begin{tabular}{cc}
\hline Ekstrak Biji Duwet 7500 ppm & Absorbansi \\
\hline I & 0,6049 \\
II & 0,6753 \\
III & 0,6296 \\
IV & 0,6256 \\
Rata-rata & 0,63385 \\
\hline
\end{tabular}

Hasil ekstrapolasi nilai absorbansi sampel kedalam persamaan kurva baku, didapatkan kadar ekstrak rata-rata sebesar 24,99 ppm kadar kuersetin didalam 7500 ppm sampel atau sampel mengandung 3,33 mg kuersetin disetiap $1 \mathrm{~g}$ sampel.

\section{Formulasi Nanopartikel Ekstrak Etanolik Biji Duwet}

Ekstrak biji duwet yang digunakan sebagai dasar pembuatan formula nanopartikel. Bahan tambahan lain yang digunakan yaitu kitosan dan Na-tpp.

Tabel 4. Formula Nanopartikel

\begin{tabular}{cccc}
\hline Formula & Kitosan & Ekstrak & Na-TPP \\
\hline 1 & 0,6 & 1,55 & 0,01 \\
2 & 0,5 & 1,55 & 0,11 \\
3 & 0,5 & 1,65 & 0,01 \\
4 & 0,55 & 1,6 & 0,01 \\
5 & 0,567 & 1,567 & 0,027 \\
6 & 0,55 & 1,55 & 0,06 \\
7 & 0,517 & 1,567 & 0,077 \\
8 & 0,533 & 1,583 & 0,043 \\
9 & 0,517 & 1,617 & 0,027 \\
10 & 0,5 & 1,55 & 0,11 \\
11 & 0,5 & 1,6 & 0,06 \\
12 & 0,6 & 1,55 & 0,01 \\
13 & 0,5 & 1,65 & 0,01 \\
\hline
\end{tabular}

a. Uji \% Entrapment Efficiency

Formula yang dibuat kemudian diambil supernatannya dan dilihat absorbansinya pada lambda maks $417 \mathrm{~nm}$ dengan operating time selama 20 menit. Nilai hasil uji entrapment efficiency 13 formula dapat dilihat pada tabel 5 .

Tabel 5. \% Entrapment Efficiency

\begin{tabular}{cc}
\hline Formula & $\boldsymbol{\%} \boldsymbol{E E}$ \\
\hline 1 & 61.6012 \\
2 & 69.3033 \\
3 & 62.7027 \\
4 & 61.5589 \\
5 & 54.0574 \\
6 & 61.3455 \\
7 & 59.1695 \\
8 & 56.1872 \\
9 & 66.1982 \\
10 & 62.8156 \\
11 & 62.6155 \\
12 & 50.4554 \\
13 & 64.3972 \\
\hline
\end{tabular}

Pada tabel 5 terlihat bahwa formula 2 memiliki nilai entrapment efficiency paling tinggi yang menandakan formula paling baik dalam menjerap ekstrak.

\section{b. Uji \% Transmittant}

Larutan campuran nanopartikel kemudian dimasukkan ke dalam kuvet dan dilihat \% transmittantnya menggunakan spektrofotometer UV-Vis pada panjang gelombang $650 \mathrm{~nm}$. Pada tabel 6 terlihat bahwa formula 9 memiliki nilai transmittant paling tinggi yang menandakan formula paling jernih.

Tabel 6. \% transmittant

\begin{tabular}{cc}
\hline Formula & \%transmittant \\
\hline 1 & 53,47 \\
2 & 40,11 \\
3 & 50,31 \\
4 & 54,00 \\
5 & 63,45 \\
6 & 53,86 \\
7 & 56,21 \\
8 & 63,23 \\
9 & 65,72 \\
10 & 40,89 \\
11 & 54,65 \\
12 & 54,52 \\
13 & 50,18 \\
\hline
\end{tabular}

\section{c. Karakterisasi Nanopartikel}

Formula nanopartikel kemudian diukur menggunakan alat particle size analyzer untuk melihat 
ukuran partikel, polidispersitas indeks, dan zeta potensial dengan hasil tertera pada tabel 7.

Dari tabel 7 dapat dilihat bahwa ukuran partikel terkecil terdapat pada formula 13 , nilai PDI terkecil pada formula 2, dan nilai zeta potensial tertinggi pada formula 5.

Tabel 7. Karakterisasi Nanopartikel

\begin{tabular}{cccc}
\hline \multirow{2}{*}{ Formula } & \multicolumn{3}{c}{ Nilai rata-rata } \\
\cline { 2 - 4 } & Ukuran Partikel $(\mathrm{nm})$ & PDI & Zeta Potensial $(\mathrm{mV})$ \\
\hline 1 & $1398,67 \pm 97,74$ & $0,63 \pm 0,24$ & $19,76 \pm 0,61$ \\
2 & $1340,00 \pm 160,50$ & $0,44 \pm 0,15$ & $21,10 \pm 1,01$ \\
3 & $820,67 \pm 49,39$ & $0,67 \pm 0,19$ & $10,70 \pm 0,65$ \\
4 & $1604 \pm 300,65$ & $0,70 \pm 0,07$ & $15,83 \pm 0,66$ \\
5 & $850,90 \pm 57,89$ & $0,68 \pm 0,11$ & $21,26 \pm 1,23$ \\
6 & $847,90 \pm 48,32$ & $0,82 \pm 0,20$ & $20,43 \pm 0,25$ \\
7 & $910,13 \pm 97,57$ & $0,87 \pm 0,21$ & $21,20 \pm 0,70$ \\
8 & $1439,33 \pm 59,51$ & $0,87 \pm 0,15$ & $18,93 \pm 0,80$ \\
9 & $1070,00 \pm 57,03$ & $0,85 \pm 0,23$ & $17,70 \pm 0,10$ \\
10 & $1104,33 \pm 23,71$ & $0,61 \pm 0,04$ & $16,60 \pm 0,55$ \\
11 & $865,76 \pm 42,13$ & $0,60 \pm 0,05$ & $14,53 \pm 0,15$ \\
12 & $994,33 \pm 66,03$ & $0,89 \pm 0,16$ & $17,16 \pm 0,65$ \\
13 & $395,90 \pm 11,83$ & $0,55 \pm 0,12$ & $16,33 \pm 0,64$ \\
\hline
\end{tabular}

Nanopartikel adalah struktrur koloid yang memiliki ukuran antara 10-1000 nm (Tiyaboonchai, 2013). Pada tabel terlihat bahwa formula $1,2,4,8,9$, dan 10 memiliki ukuran lebih dari 1000nm, sehingga 6 formula dari 13 total formula tidak memenuhi syarat sediaan nanopartikel. Sedangkan nilai PDI dan zeta potensial belum memenuhi kriteria kestabilan sediaan nanopartikel yang baik dimana nilai PDI yang baik dibawah 0,05 dan zeta potensial lebih kecil dari $-30 \mathrm{mV}$ dan lebih besar dari $+30 \mathrm{mV}$. Artinya formula nanopartikel yang dibuat belum cukup stabil.

\section{Optimasi Formula}

Berdasarkan analisis simpleks lattice design nilai desirability yang didapatkan yaitu 0,772. Nilai dari desirability maksimal adalah satu. Semakin mendekati 1,000 nilai desirability tersebut semakin baik. Berdasarkan titik tersebut maka diperoleh komposisi optimum sediaan nanopartikel ekstrak biji juwet dengan komposisi yaitu ekstrak $1,650 \mathrm{~mL}$; kitosan $0,500 \mathrm{~mL}$; dan Na-TPP 0,010 $\mathrm{mL}$. Dengan komposisi tersebut didapatkan sediaan nanopartikel dengan kriteria sebagai berikut $63,66 \%$ entrapment efficiency; 50,56\% transmittant; 615,833nm ukuran partikel; 0,620 PDI; dan zeta potensial sebesar $+13,89 \mathrm{mV}$.

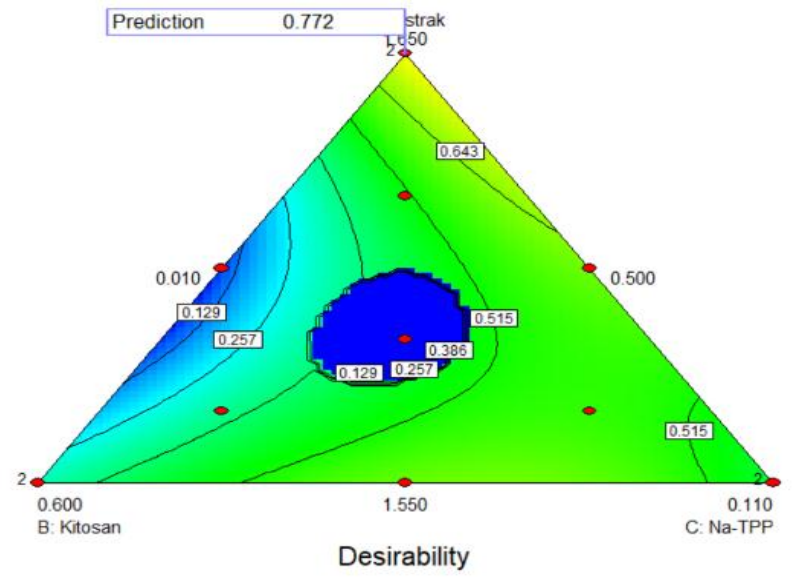

Gambar 2. Optimasi Formula

\section{Kesimpulan}

Rendemen ekstrak biji duwet diperoleh sebesar 7,44\%. Ekstrak etanolik biji juwet mengandung 3,33 mg kuersetin setiap $1 \mathrm{~g}$ ekstrak. Hasil optimasi menunjukkan komposisi ekstrak 1,650 mL; kitosan 0,500 mL; dan NaTPP $0,010 \mathrm{~mL}$ dapat memberikan hasil optimal dengan nilai desirability 0,772 yang menghasilkan kriteria 63,66\% entrapment efficiency; 50,56\% transmittant; $615,833 \mathrm{~nm}$ ukuran partikel; $0,620 \mathrm{PDI}$; dan zeta potensial sebesar $+13,89 \mathrm{mV}$. 


\section{Ucapan Terima kasih}

Penulis mengucapkan terima kasih kepada Universitas Mataram atas bantuan dana dalam penelitian ini melalui pembiayaan dari sumber dana DIPA BLU (PNBP) Universitas Mataram tahun anggaran 2019 dan juga kepada program studi farmasi, Universitas Mataram yang telah memberikan dukungan dalam pelaksanaan penelitian ini.

\section{Referensi}

Alauhdin, M. \& Widiarti, N. (2014). Sintesis dan Modifikasi Lapis Tipis Kitosan-Tripolifosfat. Jurnal MIPA. $\quad 37(1)$ : 46-52. https://journal.unnes.ac.id/nju/index.php/JM/articl e/view/3147. (Accessed on April 17, 2020).

Depkes (2009). Farmakope Herbal Indonesia. Departemen Kesehatan Republik Indonesia, Jakarta.

Faria, A.F., Marques, M.C., \& Mercadante A.Z. (2011). Identification of bioactive compounds from jambolão (Syzygium cumini) and antioxidant capacity evaluation in different $\mathrm{pH}$ conditions. Food Chemistry, 126: 1571-1578. DOI: 10.1016/j.foodchem.2010.12.007.

George, M. \& Abraham, T.E. (2006). Polyionic hydrocolloids for the intestinal delivery of protein drugs: Alginate and chitosan - a review. Journal of Controlled Release, 114: 1-14. DOI: 10.1016/j.jconrel.2006.04.017.

Holstein, A. \& Egberts, E.H. (2003). Risk of Hypoglycaemia with Oral Antidiabetic Agents in Patients with Type 2 Diabetes. Experimental and Clinical Endocrinology \& Diabetes, 111: 405414. DOI: $10.1055 / \mathrm{s}-2003-44287$.

Khairani, R. (2007). Prevalensi diabetes melitus dan hubungannya dengan kualitas hidup lanjut usia di masyarakat. Universa Medicina, 26: 9. DOI: http://dx.doi.org/10.18051/UnivMed.2007.v26.18 -26 .

Kumar, A., Ilavarasan, R., Jayachandran, T., Deecaraman, M., Aravindan, P., Padmanabhan, N. \& Krishan, M.R.V. (2008). Anti-diabetic activity of Syzygium cumini and its isolated compound against streptozotocin-induced diabetic rats. Journal of Medicinal Plants Research, 2(9): 246-249. https://academicjournals.org/article/article138038
1651_Kumar et al.pdf (Accessed on April 20, 2020).

Lin, Y.H., Sonaje, K., Lin, K.M., Juang, J.H., Mi, F.L., Yang, H.W. \& Sung, H.W. (2008). Multi-ioncrosslinked nanoparticles with $\mathrm{pH}$-responsive characteristics for oral delivery of protein drugs. Journal of Controlled Release, 132: 141-149. DOI: 10.1016/j.jconrel.2008.08.020.

Murdock, R.C., Braydich-Stolle, L., Schrand, A.M., Schlager, J.J. \& Hussain, S.M. (2008). Characterization of Nanoparticle Dispersion in Solution Prior to In Vitro Exposure using Dynamic Light Scattering Technique. Toxicol Sci, 101: 239253. DOI: $10.1093 /$ toxsci/kfm240.

Qaseem, A., Humphrey, L.L., Sweet, D.E., Starkey, M. \& Shekelle, P. (2012). Oral Pharmacologic Treatment of Type 2 Diabetes Mellitus: A Clinical Practice Guideline from the American College of Physicians. Annals of Internal Medicine, 156(3): 218. DOI: 10.7326/0003-4819-156-3-20120207000011.

Ramadhan, L.O.A.N., Radiman, C.L., Wahyuningrum, D., Suendo, V., Ahmad, L.O. \& Valiyaveetiil, S. (2010). Deasetilasi Kitin Bertahap dan Pengaruhnya terhadap Derajat Deasetilasi serta massa molekul kitosan. Jurnal Kimia Indonesia, 5(1): $\quad$ 17-21. http://karyailmiah.uho.ac.id/karya_ilmiah/Ahmad _Mipa/18_Deasetilasi_kitin.pdf (Accessed on April 17, 2020).

Stamatialis, D.F., Papenburg, B.J., Giron'es, M., Saiful, S., Bettahalli, S.N.M., Schmitmeier, S. \& Wessling M. (2008). Medical applications of membraness: Drug delivery, artificial organ and tissue engineering. J Membrane Sciences, 308: 134. DOI:10.1016/J.MEMSCI.2007.09.059.

Schipper, N.G.M., Olsson, S., Hoogstraate, J.A., deBoer, A.G., Vårum, K.M. \& Artursson, P. (1997). Chitosan as absortion enhancers for poorly absorbable drugs 2: mechanism of absorbtion. Pharmaceutical Research, 14: 923-929. DOI: 10.1023/a: 1012160102740.

Sharma, B., Balomajumder, C. \& Roy, P., (2008). Hypoglycemic and hypolipidemic effects of flavonoid rich extract from Eugenia jambolana seeds on streptozotocin induced diabetic rats. Food and Chemical Toxicology, 46: 2376-2383. DOI: 10.1016/j.fct.2008.03.020. 
Swami, S.B., Thakor, N.S.J., Patil, M.M. \& Haldankar, P.M. (2012). Jamun (Syzygium cumini (L.)): A Review of Its Food and Medicinal Uses. Food and Nutrition Sciences, 3(8): 1100-1117. DOI: http://dx.doi.org/10.4236/fns.2012.38146.

Tiyaboonchai, W. (2013). Chitosan Nanoparticles: A Promising System for Drug Delivery. Naresuan University Journal, 11 (3): 51-66. http://www.journal.nu.ac.th/NUJST/article/view/2 50.htm (Accessed on Mei 19, 2020).

Zhang, M., Li, X.H., Gong, Y.D., Zhao, N.M. \& Zhang, X.F. (2002). Properties and biocompatibility of chitosan films modified by blending with PEG. Biomaterials, 23(13): 2641-2648. DOI: 10.1016/s0142-9612(01)00403-3. 